\title{
Entry Point A Initiatives as an Example for the Sustainable Approach in the Watershed Programme in Anantapur District, Andhra Pradesh
}

\author{
P. V. R. M. Reddy ${ }^{1}$, B. Janardha Reddy ${ }^{1}$, B. V. Ramana Kumar ${ }^{2}$, \\ R. Jhansi Rani ${ }^{2 *}$ and Pullanna Vidyapogu ${ }^{2}$ \\ ${ }^{1}$ Watersheds, State Level Nodal Agency, Andhra Pradesh, India \\ ${ }^{2}$ Remote Sensing Instruments, Plot No.7, Type-I, Industrial Estate, Kukatpally, \\ Hyderabad, India \\ *Corresponding author
}

\section{Keywords}

Watershed, Entry Point Activities, Community, Grama sabha, Ownership

Article Info

\section{Accepted:}

12 March 2021

Available Online:

10 April 2021

\section{A B S T R A C T}

The community plays a key role in defining and organizing aspects of all the required works for their village in the watershed program. The position in the Entry Point Activities is evident in the implementation of works that were taken up in watershed project area. In Grama Sabha, all the entry point activities were identified through consultation with the village's public and they ensure that all categories of communities have participated such as SC, ST, and women's groups and so on. The Grama Sabha and watershed committee facilitated the initiation of entry point activities (EPAs) throughout the process. The EPAs have been identified based on the need and priority in the villages which takes care of interest of community. In preparatory phase, Entry Point Activities towards community oriented works like animal health camps, trevices, water purification plants, solar street plants, cattle drinking troughs have been identified and taken up as per the need in micro watershed villages in the first year to introduce watershed concepts into community using $4 \%$ project funds. When they were involved in all steps, the community was able to maintain ownership of the entry point activities.

\section{Introduction}

The research paper is focused on the importance and role of community in implementation of Entry Point Activities at the watershed project area. Definition of entry point activities as per watershed programme is
"The project initiation activities that make the village community feel the entry of a watershed project in the village. It helps the confidence building among the village community". The report is covered for BatchIII watershed projects of Anantapur district of Andhra Pradesh. 


\section{Objectives}

Comprehending the importance of community participation in Entry Point Activities to initiate village watershed activities

Consider the preferences of the community and goals for village growth

\section{Materials and Methods}

The study is emphasized on the various works taken up under the Entry Point Activities in watershed villages and the relevant data collected from the District Water Management Agency (DWMA), Anantapur district and secondary data collected through the relevant case studies in the project area. The data tabulated and analyzed project wise, gram panchayat wise, activity wise and EPA wise.

The study selected for Dharamavaram, Anantapur district of Andhra Pradesh area has of 4 major watershed projects of Anantapur districts from Batch -III.

\section{Initiation of Watershed Project}

The Government of Andhra Pradesh being pioneer in the country in conserving natural resources by adopting Watershed approach has created a separate Commissionerate for Rural Development for carrying out programme across the entire state in the coming years. All the criteria proposed by the Department of Land Resource, Government of India have been used for prioritizing the Watershed. Based on this, more critical one's as to be treated on priority. Further, taking into priority ranking given by APSRAC denotes that SC, ST population, percentage of literacy, percentage of agricultural labour, status of groundwater, scarcity of drinking water, quality of drinking water, availability of DWCRA, contiguity with existing watersheds, livestock population, community mobilization etc. About 3,600 watersheds were prioritized into very high, high, medium, low and very low categories across the state. In this view Anantapur district implemented 86 watershed projects since 2009- 10. For administrative ease, watershed projects in Anantapur districts were divided and implemented in batches.

\section{Process of watershed project at gross root level}

The major activities of the Watershed Development projects were carried out in three phases comprised as (i) Preparatory phase, (ii) Works phase and (iii) Consolidation phase. The project duration could be in the range of four to seven years. During the preparatory phase, Entry Point Activities such as community-oriented works such as cattle troughs, school furniture, water purification plants, solar street plants, and tent house material were undertaken as needed in micro watershed villages during the first year to bring watershed concepts into the community using $4 \%$ project funds. The major objective of this phase is to build appropriate mechanisms for adoption of participatory approach and empowerment of local institutions. In this phase, the main activities consist:

Taking up entry point activities to establish credibility of the Watershed Development Team (WDT) and create a rapport with the village community. The entry point activities, inter-alia, will include:

Works based on urgent needs of the local communities such as revival of common natural resources, drinking water, development of local energy potential, augmenting ground water potential etc.

Repair, restoration and up gradation of existing common property assets and structures (such as village tanks) may be 
undertaken to obtain optimum and sustained benefits from previous public investments and traditional water harvesting structures.

Productivity enhancement of existing farming systems could also be an activity that helps in community mobilization and building rapport.

\section{Role of Community Participation in Entry Point Activities}

In the preparatory process, Entry Point activities such as community-oriented works like cattle troughs, solar street lights, water purification plants, school furniture, pipe lines were taken up during the first year in micro watershed villages to use 4 percent project funding to introduce watershed concepts into the villages. Involvement of primary stakeholders is at the centre of planning, budgeting, implementation, and management of watershed projects. Community organizations are closely associated with and accountable to Gram Sabhas in project activities.

Under the new guidelines of IWMP, nearly $4 \%$ of the total watershed budget is earmarked for Entry point activities (EPA) to be spent for the needs of the watershed/village beneficiaries in the first year of preparatory phase and to develop their confidence in implementing all watershed activities planned under watershed development project.

The EPA is envisaged to build a rapport between Project Implementing Agency (PIA) and rural people before initiating watershed programs. Usually, entry point intervention/activity is identified through PRA and Grama Sabha meetings. It involves building rapport with community, strengthening and sustaining it throughout the program and thereafter. In reality, it involves a lot of time and resources of project staff and could determine the success or failure of program. A carefully laid out EPA could address community's aspiration and capitalize on it by ensuring larger peoples' participation in all watershed activities.

\section{Identification of Entry Point activities}

Generally, EPAs' were identified through Grama Sabha and watershed stakeholders meet to identify the immediate needs of the community instead of individual needs. Moreover, EPAs' are so chosen and done as to develop the rapport between the project implementing agency (PIA) and the rural people before initiating watershed programs.

\section{Study Area}

Dharamravaram projects selected for thematic analysis to provide an example of successful entry point activities. The study selected projects for Kunukuntla, Darsimala, Mustikovela, and Nasanakota projects.

\section{Kunukuntla Watershed Project}

Kunukuntla IWMP watershed project is located in DPAP of Tadimarri mandal of Anantapur district. This IWMP watershed project is located between the latitudes $14^{0} 34$ '09" to longitude $77^{0} 53$ ' 40 " at ridge point and between latitude $14^{0} 33^{\prime} 31^{\prime \prime}$ to longitude $77^{0} 5327 "$ at valley point. The total geographical area of this watershed project is $5,876 \mathrm{Ha}$ and net treatable area is $4,436 \mathrm{Ha}$. The average annual rainfall (10 years) in the area is $477 \mathrm{~mm}$.

The temperatures in the area are in the range between $41^{\circ} \mathrm{C}$ during summer and $27^{\circ} \mathrm{C}$ during winter. There are 7 habitations in this watershed project. At present this watershed project is having 6,380 population with all communities like SC, ST, BC, Minorities and others. This watershed project consists of 5 micro-watersheds. 
Entry Point Activities in Kunukuntla Watershed Project

Activities at the Entry point were carried out in 5 Gram Panchyatas that includes 5 habitations. EPA works such as Cattle Troughs (11), Drums (4), School Furniture (9), Tent House (4), Tailoring Machine (6), Solar Street Lights (9), 10W Led Street Light (2) and Village Organization Furniture (3).

Entry Point Events based on needs and requirements were chosen for the population in the watershed villages. A sum of Rs. 21,22,109 (Twenty-One Lakh Twenty-Two Thousand One Hundred and Nine Rupees) was spent in total 48 EPA activities. The EPA activities found the villagers to be extremely useful. The village community has given importance to school infrastructure such as school furniture \& water drums, streetlights, drinking water facilities to animals, and also cattle troughs etc.

\section{Darsimala watershed project}

Darsimala IWMP watershed project is located in DPAP block of Dharmavarm Mandal, Anantapur district. This watershed project is located between the latitudes $14^{\circ} 20^{\prime} 33^{\prime \prime} \mathrm{N}$ to longitude $77^{\circ} 50^{\prime} 12^{\prime \prime} \mathrm{E}$ at ridge point and between latitude $14^{\circ} 21^{\prime} 36^{\prime \prime} \mathrm{N}$ to longitude $76^{\circ}$ 50 '22" E at valley point. The total geographical area of this watershed project is 4,455 hectares and net treatable area is 3,425 hectares.

The average annual rainfall (10 years) in the area is $563.37 \mathrm{~mm}$. The temperatures in the area are in the range between $40^{\circ}$ centigrade during summer and $29^{\circ}$ centigrade during winter. There are 5 habitations in this watershed project. At present this watershed project is having 4,634 populations with all communities like SC, ST, BC, Minorities and others.

\section{Entry Point Activities in Darsimala Watershed Project}

Activities at the Entry point were carried out in 3 Gram Panchyatas that includes 5 habitations. EPA activities such as cattle troughs (11), drums (1), Solar Street Lights (8) Music set (1), purified water plant (2), Tent House (4) and Village Organization furniture (2).

Entry Point Activities based on need and community preference were selected for the community in the watershed villages. Totally 22 EPA activities were carried out and spent an amount of Rs. 16,41,146 (Sixteen Lakh Forty-One Thousand One Hundred and FortySix rupees). The EPA activities were found extremely useful to the villagers.

The village community has given importance to the school infrastructure such as Cattle troughs, Street lights such the below given table explained village wise various EPA activities.

\section{Mustikovela Watershed Project}

Mustikovela watershed project is located in DPAP block of Chenne Kothapalli mandal, Anantapur district. This IWMP watershed project is located between the latitudes $14^{0} 10^{\prime} 31^{\prime \prime}$ to longitude $77^{0} 30^{\prime} 17^{\prime \prime}$ at ridge point and between latitude $14^{0} 11$ ' $00^{\prime \prime}$ to longitude $77^{0} 30^{\prime} 57^{\prime \prime}$ at valley point.

The total geographical area of this watershed project is $6,006 \mathrm{Ha}$ and net treatable area is 4,608 Ha. The average annual rainfall (10 years) in the area is $372 \mathrm{~mm}$. The temperatures in the area range between $42^{\circ} \mathrm{C}$ during summer and $22^{\circ} \mathrm{C}$ during winter. There are 4 habitations in this watershed project. At present this watershed project is having 4,577 population with all communities like SC, ST, $\mathrm{BC}, \mathrm{OC}$ and minorities. 
Entry Point Activities in Mustikovela Watershed Project

The Entry point activities were carried out in 1 Gram Panchyata which includes 3 Habitations. The EPA activities like cattle troughs (12), Construction of GLSR(1), Drums (1), Furniture to schools(3), Carpet to temple (1), Pipe line and submersible Pump sets(1), Repair of Racha Katta (1),Solar Street Lights (25), Supply of sports kit(1), tent house (1) and water plnat (1). Totally 48 EPA activities were carried and spent an amount of Rs. 22,10,981 (Twenty- Two Lakh Ten Thousand Nine Hundred Eighty-One).The EPA activities were found extremely useful to the villagers. The village community has given importance the school infrastructure, solar street lights, water plant etc., and the below given table explained village wise various EPA activities.

\section{Nasanakota Watershed Project}

Nasanakota IWMP watershed project is located in DPAP block of Ramagiri mandal, Anantapur district. This IWMP watershed project is located between the latitudes $14^{\circ} 19^{\prime} 33^{\prime \prime}$ to longitude $77^{\circ} 27^{\prime} 41^{\prime \prime}$ at ridge point and between latitude $14^{\circ} 20^{\prime} 17^{\prime \prime}$ to longitude $77^{\circ} 25^{\prime} 00^{\prime \prime}$ at valley point. The total geographical area of watershed project is 5,297 $\mathrm{Ha}$ and net treatable area is 4,333 $\mathrm{Ha}$. The average annual rainfall (10 years) in the area is $390 \mathrm{~mm}$. The temperatures in the area range between $42^{\circ} \mathrm{C}$ during summer and $23^{\circ} \mathrm{C}$ during winter. There are 8 habitations in watershed project. At present this village is having 3010 population with all communities like SC, ST, BC, minorities and others.

\section{Entry Point Activities in Nasanakota Watershed Project}

The Entry point activities were carried out in 2 Gram Panchyatas which includes 8 habitations. The EPA activities like cattle troughs (25), Construction of cistern (2), Furniture to schools (6), RO water plant (1), Solar inverter(1), Solar street lights (10), tent house (3), Water plant 1000LPH (1)Totally 49 EPA activities were carried and spent an amount of Rs. 20,74,449 (Twenty Lakh Seventy-Four Thousand Four Hundred FortyNine rupees).The EPA activities found the excellent useful to the villagers. The village community has given importance cattle troughs, solar street lights, tent House etc., and the below given table explained village wise various EPA activities.

\section{Results and Discussion}

The community of the watershed villages have been given preference to the overall village development activities such as cattle trough, solar street lights, school furniture, tent house, water drums, Tailor machine, water plants etc., The table-9 explained about the overall EPA activities in 4 watershed projects.

Totally 17 major EPA activities were carried out in 11 Gram Panchayats and 21 habitations of 4 watershed projects, among those, community majorly preferred cattle troughs, solar street lights, school furniture, tent house material Tailor machine and purified water plant etc.,

In total, 4 watershed projects and 174 different EPA activities were covered in 11 major Gram Panchayats, which included 21 habitations. Kunukuntla project covered 5 major Gram panchayats and 5 habitations and carried out 48 EPA activities, whereas Darsimala project covered 3 Gram Panchayats and 5 habitations and carried out 29 EPA activities. Mustikovila completed 48 EPA activities while covering one major Gram Panchayat and three habitations. Nasanakota, which has two Gram Panchayats and eight habitations, was responsible for 49 different EPA activities. The total expenditure for all 174 EPA 
activities in 4 projects in Dharmavaram mandal of Ananthapur district is Rs.80,48,685/-.The various activities under Entry Point Activities were explained below, with a few key activities highlighted.

\section{Cattle Troughs}

The importance of addressing the needs of the livestock was placed on the village community. Despite their importance, livestock are frequently overlooked in agricultural water planning and management, particularly when it comes to water requirements for fodder crops. Drinking water for livestock is frequently available in rural domestic supply. Animals must travel long distances in many areas of the district, especially in dry areas during the summer season. It is extremely difficult to obtain sufficient water during animal grazing in districts such as Anantapur. The watershed committee and the community have decided to provide water sources for animals such as cows, buffalos, goats, and sheep. Enough water was provided by the construction of animal water troughs. Water troughs are typically built along roadsides in villages, as well as at animal grazing areas.

\section{Solar Street Lights}

Solar streetlights have received a tremendous response, and they represent a significant achievement in the selected areas. With the ultimate goal of improving rural communities' living standards by connecting them to renewable energy, the watershed programme has undertaken a novel initiative by installing solar streetlights and delivering efficient and effective solar-powered village lighting. The village community effectively repairs and maintains the solar streetlights on a regular basis.

\section{School Furniture and Sports Material to the Children}

The community has realized the importance of educating the children and their facilities, and has provided through EPA school furniture such as school benches, school computer tables, library furniture, etc., all of which shows is the shift of the rural community towards school facilities and infrastructure that assists children's educational success. Also, the school teachers and the department of education are tremendously happy to have contributions from the watershed program to the school which would be useful for improvement of the education level. School children also improved their attitude towards the village's watershed management and holistic overall growth.

\section{RO Water Plants}

Safe drinking water is a very common problem in drought prone areas and lack of sufficient safe drinking water in the watershed project region, resulted frequent occurrence of disease among rural poor people, and spending a lot of money on hospitals, due to polluted water use, etc. The village community has strongly decided to have a safe drinking water facility through EPA of watershed program through RO plants and water plants, etc. The RO water plants has been maintained in the watershed villages very well by the community, thus saved money spent towards purchase of water as well as time which was allocating to bring water from for off place. Nearly $4 \%$ of the budg et al., located for innovative entry point activities (EPA) under the IWMP guidelines which were used effectively to meet the needs of the watershed community and to build a good relationship for the smooth implementation of the watershed, and this effort was successful. 
Table.1 Details of Micro-watersheds in Kunukuntla Watershed Project

\begin{tabular}{|c|c|c|c|c|c|}
\hline $\begin{array}{c}\text { S. } \\
\text { No. }\end{array}$ & $\begin{array}{c}\text { Name of the Micro- } \\
\text { watershed }\end{array}$ & $\begin{array}{c}\text { Net Area } \\
\text { Proposed } \\
\text { (Ha) }\end{array}$ & $\begin{array}{c}\text { No. of } \\
\text { Habitations }\end{array}$ & $\begin{array}{c}\text { No. of House } \\
\text { Holds }\end{array}$ & Population \\
\hline $\mathbf{1}$ & Bangarampeta & 831 & 1 & 102 & $\mathbf{1 5 6}$ \\
\hline $\mathbf{2}$ & Chillakondaihpalli & 992 & 2 & 450 & $\mathbf{1 , 6 1 0}$ \\
\hline $\mathbf{3}$ & Kunukuntla & 1,435 & 1 & 401 & $\mathbf{2 , 0 7 2}$ \\
\hline $\mathbf{4}$ & Peddakotla & 736 & 2 & 760 & $\mathbf{1 , 5 2 7}$ \\
\hline $\mathbf{5}$ & Ramapuram & 512 & 1 & 280 & $\mathbf{1 , 0 1 5}$ \\
\hline & Total & $\mathbf{4 , 4 3 6}$ & $\mathbf{7}$ & $\mathbf{1 , 9 9 3}$ & $\mathbf{6 , 3 8 0}$ \\
\hline
\end{tabular}

Table.2 Total Entry Point Activities -Kunukuntla Project

\begin{tabular}{|c|c|c|}
\hline S. No & Name of the EPA & Units \\
\hline $\mathbf{1}$ & Cattle troughs & $\mathbf{1 1}$ \\
\hline $\mathbf{2}$ & Drums & $\mathbf{4}$ \\
\hline $\mathbf{3}$ & School Furniture & $\mathbf{9}$ \\
\hline $\mathbf{4}$ & Tent house & $\mathbf{4}$ \\
\hline $\mathbf{5}$ & Tailor Machine & $\mathbf{6}$ \\
\hline $\mathbf{6}$ & Solar streetlights & $\mathbf{9}$ \\
\hline $\mathbf{7}$ & fixing of 10w led streetlight & $\mathbf{2}$ \\
\hline $\mathbf{8}$ & VO furniture & $\mathbf{3}$ \\
\hline & Grand Total & $\mathbf{4 8}$ \\
\hline
\end{tabular}

Table.3 Details of Micro-watersheds in Darsimala Watershed Project

\begin{tabular}{|c|c|c|c|c|c|}
\hline S. No. & $\begin{array}{c}\text { Name of the Micro- } \\
\text { watershed (MWS) }\end{array}$ & $\begin{array}{c}\text { Net Area } \\
\text { Proposed (Ha) }\end{array}$ & $\begin{array}{c}\text { No. of } \\
\text { Habitation } \\
\text { S }\end{array}$ & $\begin{array}{c}\text { No. of } \\
\text { House } \\
\text { Holds }\end{array}$ & Population \\
\hline $\mathbf{1}$ & Bommayapalle & 935 & 1 & 155 & $\mathbf{7 9 3}$ \\
\hline $\mathbf{2}$ & Darsimala & 1,360 & 2 & 745 & $\mathbf{2 , 4 3 8}$ \\
\hline $\mathbf{3}$ & Venkata Thimmapurum & 1,130 & 2 & 600 & $\mathbf{1 , 4 0 3}$ \\
\hline & Total & $\mathbf{3 , 4 2 5}$ & $\mathbf{5}$ & $\mathbf{1 , 5 0 0}$ & $\mathbf{4 , 6 3 4}$ \\
\hline
\end{tabular}

Table.4 Total Entry Point Activities Darsimala project

\begin{tabular}{|c|c|c|}
\hline S. No & Name of the EPA & Units \\
\hline $\mathbf{1}$ & Cattle troughs & $\mathbf{1 1}$ \\
\hline $\mathbf{2}$ & Drums & $\mathbf{1}$ \\
\hline $\mathbf{3}$ & Solar Street lights & $\mathbf{8}$ \\
\hline $\mathbf{4}$ & Music set & $\mathbf{1}$ \\
\hline $\mathbf{5}$ & Purified water plant & $\mathbf{2}$ \\
\hline $\mathbf{6}$ & Tent house & $\mathbf{4}$ \\
\hline $\mathbf{7}$ & VO furniture & $\mathbf{2}$ \\
\hline & Grand Total & $\mathbf{2 9}$ \\
\hline
\end{tabular}


Table.5 Details of Micro-watersheds in Mustikovela Watershed Project

\begin{tabular}{|c|c|c|c|c|c|}
\hline S. No. & $\begin{array}{c}\text { Name of the Micro- } \\
\text { watershed (MWS) }\end{array}$ & $\begin{array}{c}\text { Net Area } \\
\text { Proposed (Ha) }\end{array}$ & $\begin{array}{c}\text { No. of } \\
\text { Habitations }\end{array}$ & $\begin{array}{c}\text { No. of House } \\
\text { Holds }\end{array}$ & Population \\
\hline $\mathbf{1}$ & Guvvalagondipalle & 2,909 & 1 & 540 & $\mathbf{1 , 5 6 7}$ \\
\hline $\mathbf{2}$ & Mustikovela & 913 & 1 & 680 & $\mathbf{1 , 4 5 0}$ \\
\hline $\mathbf{3}$ & Subbarayana palle & 786 & 2 & 270 & $\mathbf{1 , 5 6 0}$ \\
\hline & Total & $\mathbf{4 , 6 0 8}$ & $\mathbf{4}$ & $\mathbf{1 , 4 9 0}$ & $\mathbf{4 , 5 7 7}$ \\
\hline
\end{tabular}

Table.6 Total Entry Point Activities in Mustikovela Watershed Project

\begin{tabular}{|c|c|c|}
\hline S. No & Name of the EPA & Units \\
\hline $\mathbf{1}$ & Cattle troughs & $\mathbf{1 2}$ \\
\hline $\mathbf{2}$ & Construction of GLSR. & $\mathbf{1}$ \\
\hline $\mathbf{3}$ & Drums & $\mathbf{1}$ \\
\hline $\mathbf{4}$ & Furniture to school & $\mathbf{3}$ \\
\hline $\mathbf{5}$ & Carpet for temple & $\mathbf{1}$ \\
\hline $\mathbf{6}$ & Providing pipeline and Sub mersibul pump set & $\mathbf{1}$ \\
\hline $\mathbf{7}$ & Repair of Racha Katta & $\mathbf{1}$ \\
\hline $\mathbf{8}$ & Solar Street lights & $\mathbf{2 5}$ \\
\hline $\mathbf{9}$ & Supply of sports kit & $\mathbf{1}$ \\
\hline $\mathbf{1 0}$ & tent house & $\mathbf{1}$ \\
\hline $\mathbf{1 1}$ & Water plant & $\mathbf{1}$ \\
\hline & Grand Total & $\mathbf{4 8}$ \\
\hline
\end{tabular}

Table.7 Details of Micro-watersheds in Nasanakota Watershed Project

\begin{tabular}{|c|c|c|c|c|c|}
\hline $\begin{array}{c}\text { S. } \\
\text { No. }\end{array}$ & $\begin{array}{c}\text { Name of the Micro- } \\
\text { watershed (MWS) }\end{array}$ & $\begin{array}{c}\text { Net Area } \\
\text { Proposed } \\
(\mathbf{H a})\end{array}$ & $\begin{array}{c}\text { No. of } \\
\text { Habitations }\end{array}$ & $\begin{array}{c}\text { No. of } \\
\text { House Holds }\end{array}$ & Population \\
\hline $\mathbf{1}$ & Madhapuram & 1,512 & 3 & 340 & $\mathbf{1 , 2 0 0}$ \\
\hline $\mathbf{2}$ & Mutyalampalli & 1,200 & 2 & 285 & $\mathbf{6 2 0}$ \\
\hline $\mathbf{3}$ & Nasanakonta & 1,621 & 3 & 880 & $\mathbf{1 , 1 9 0}$ \\
\hline & Total & $\mathbf{4 , 3 3 3}$ & $\mathbf{8}$ & $\mathbf{1 , 5 0 5}$ & $\mathbf{3 , 0 1 0}$ \\
\hline
\end{tabular}

Table.8 Total Entry Point Activities in Nasanaknta Watershed Project

\begin{tabular}{|c|c|c|}
\hline S. No & Name of the EPA & Units \\
\hline $\mathbf{1}$ & Cattle troughs & $\mathbf{2 5}$ \\
\hline $\mathbf{2}$ & Construction of cistern & $\mathbf{2}$ \\
\hline $\mathbf{3}$ & School furniture & $\mathbf{6}$ \\
\hline $\mathbf{4}$ & RO water plant & $\mathbf{1}$ \\
\hline $\mathbf{5}$ & Solar inverter & $\mathbf{1}$ \\
\hline $\mathbf{6}$ & Solar Street lights & $\mathbf{1 0}$ \\
\hline $\mathbf{7}$ & Tent House & $\mathbf{3}$ \\
\hline $\mathbf{8}$ & Water plant 1000 L.P.H & $\mathbf{1}$ \\
\hline & Grand Total & $\mathbf{4 9}$ \\
\hline
\end{tabular}


Table.9 Overall EPA activities in 4 watershed projects

\begin{tabular}{|c|c|c|}
\hline S. No & Name of the EPA & No. of Units \\
\hline $\mathbf{1}$ & Cattle trough & $\mathbf{5 9}$ \\
\hline $\mathbf{2}$ & Solar streetlights & $\mathbf{5 2}$ \\
\hline $\mathbf{3}$ & School furniture & $\mathbf{1 8}$ \\
\hline $\mathbf{4}$ & Tent house & $\mathbf{1 2}$ \\
\hline $\mathbf{5}$ & Drums & $\mathbf{6}$ \\
\hline $\mathbf{6}$ & Tailor machine & $\mathbf{6}$ \\
\hline $\mathbf{7}$ & Purified water plant & $\mathbf{5}$ \\
\hline $\mathbf{8}$ & VO furniture & $\mathbf{5}$ \\
\hline $\mathbf{9}$ & Construction of cistern & $\mathbf{2}$ \\
\hline $\mathbf{1 0}$ & fixing of 10w led streetlight & $\mathbf{2}$ \\
\hline $\mathbf{1 1}$ & Carpet for temple & $\mathbf{1}$ \\
\hline $\mathbf{1 2}$ & Construction of GLSR & $\mathbf{1}$ \\
\hline $\mathbf{1 3}$ & Music set & $\mathbf{1}$ \\
\hline $\mathbf{1 4}$ & Providing pipeline and Sub mersibul pumpset & $\mathbf{1}$ \\
\hline $\mathbf{1 5}$ & Repair of Racha Katta & $\mathbf{1}$ \\
\hline $\mathbf{1 6}$ & Solar inverter & $\mathbf{1}$ \\
\hline $\mathbf{1 7}$ & Supply of sports kit & $\mathbf{1}$ \\
\hline & Grand Total & $\mathbf{1 7 4}$ \\
\hline
\end{tabular}

Table.10 Project-wise EPA and Expenditure

\begin{tabular}{|c|c|c|c|c|c|}
\hline $\begin{array}{c}\text { S. } \\
\text { No }\end{array}$ & Name of the Project & $\begin{array}{c}\text { No Gram } \\
\text { panchyats }\end{array}$ & $\begin{array}{c}\text { No } \\
\text { Habitations }\end{array}$ & $\begin{array}{c}\text { Units of } \\
\text { EPA }\end{array}$ & $\begin{array}{c}\text { Total } \\
\text { expenditure }\end{array}$ \\
\hline $\mathbf{1}$ & Kunukuntla & 5 & 5 & 48 & $\mathbf{2 1 , 2 2 , 1 0 9}$ \\
\hline $\mathbf{2}$ & Darsimala & 3 & 5 & 29 & $\mathbf{1 6 , 4 1 , 1 4 6}$ \\
\hline $\mathbf{3}$ & Mustikovela & 1 & 3 & 48 & $\mathbf{2 2 , 1 0 , 9 8 1}$ \\
\hline $\mathbf{4}$ & Nasanakota & 2 & 8 & 49 & $\mathbf{2 0 , 7 4 , 4 4 9}$ \\
\hline & Grand total & $\mathbf{1 1}$ & $\mathbf{2 1}$ & $\mathbf{1 7 4}$ & $\mathbf{8 0 , 4 8 , 6 8 5}$ \\
\hline
\end{tabular}

Graph.1 Total EPA activities-Kunukuntla Project

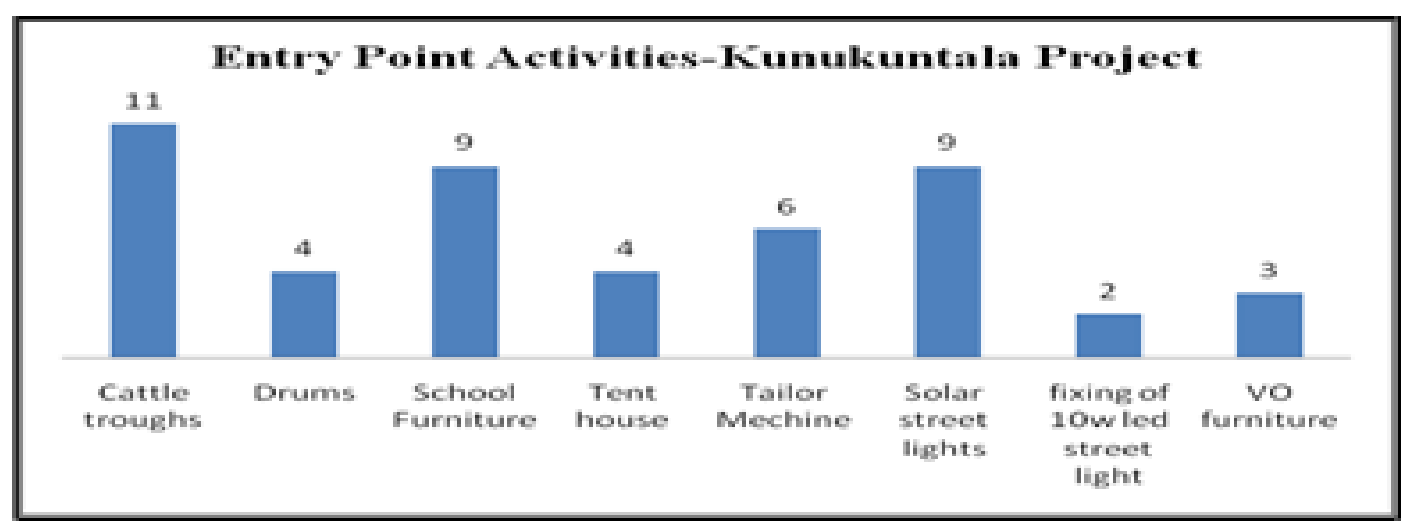


Graph.2 Total EPA activities- Darsimala Project

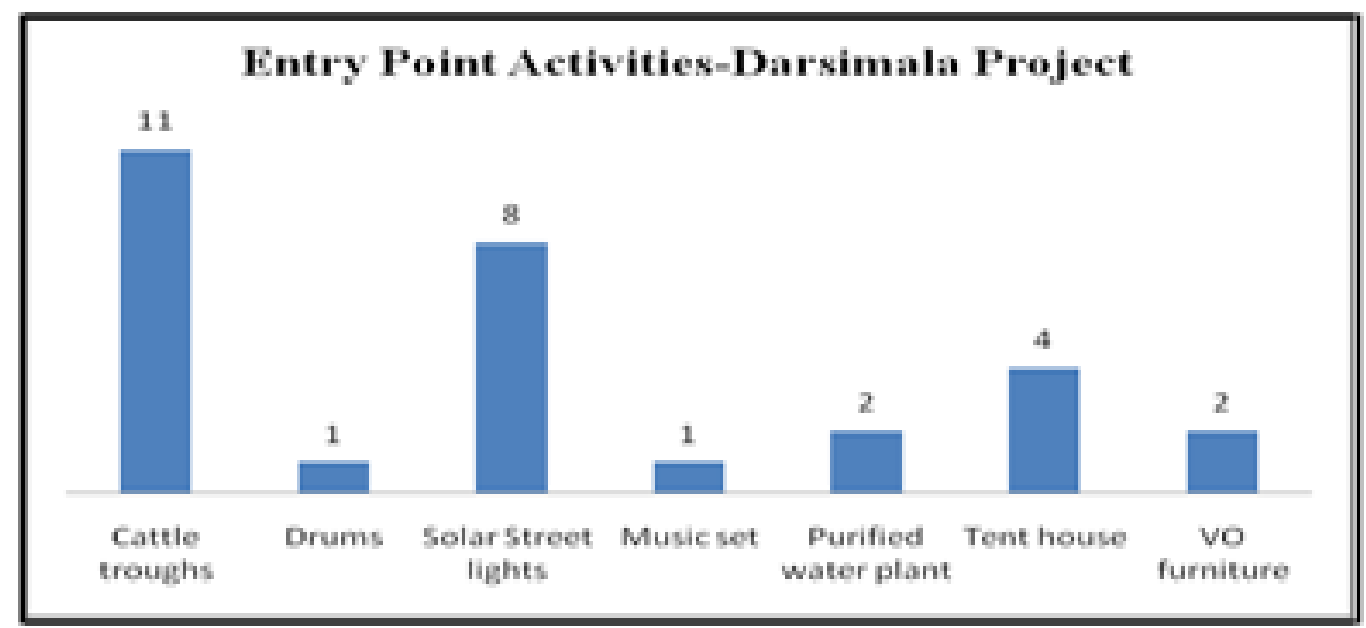

Graph.3 Total EPA activities-Mustikovela Project

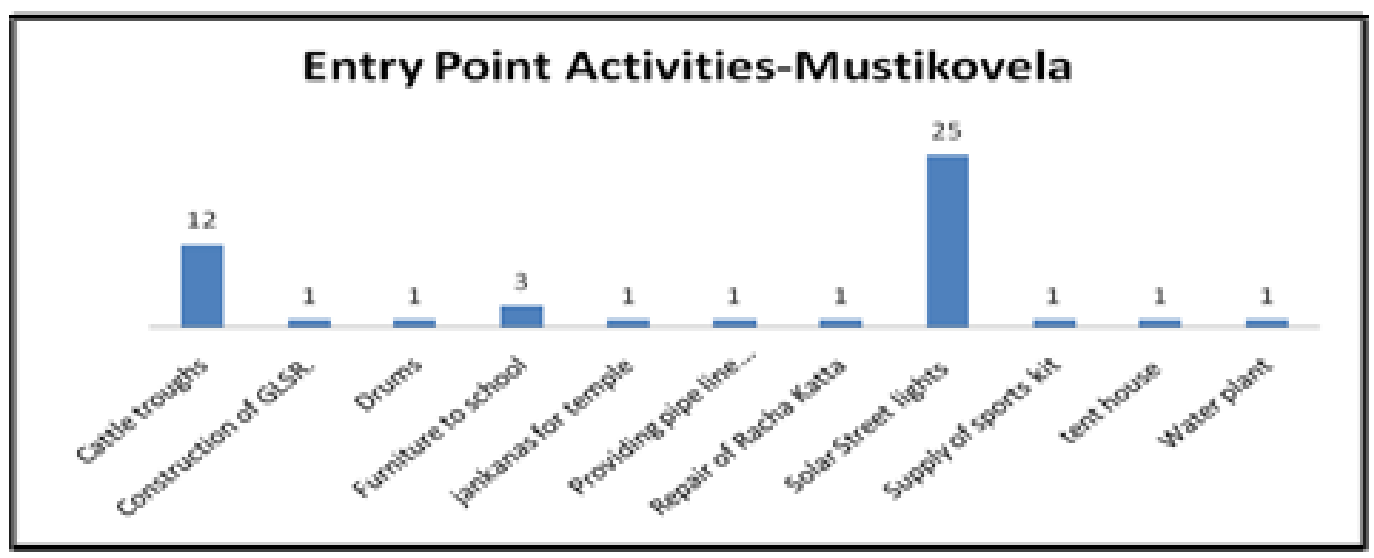

Graph.4 Total EPA activities- Nasanakota Project

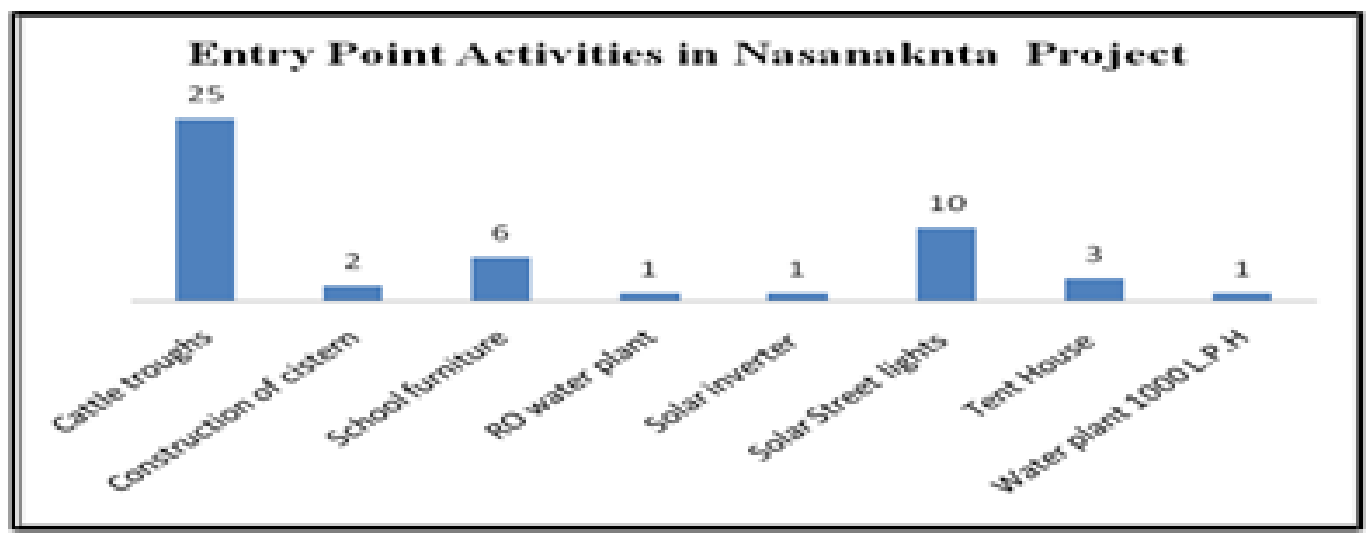


Graph.5 Project wise EPA

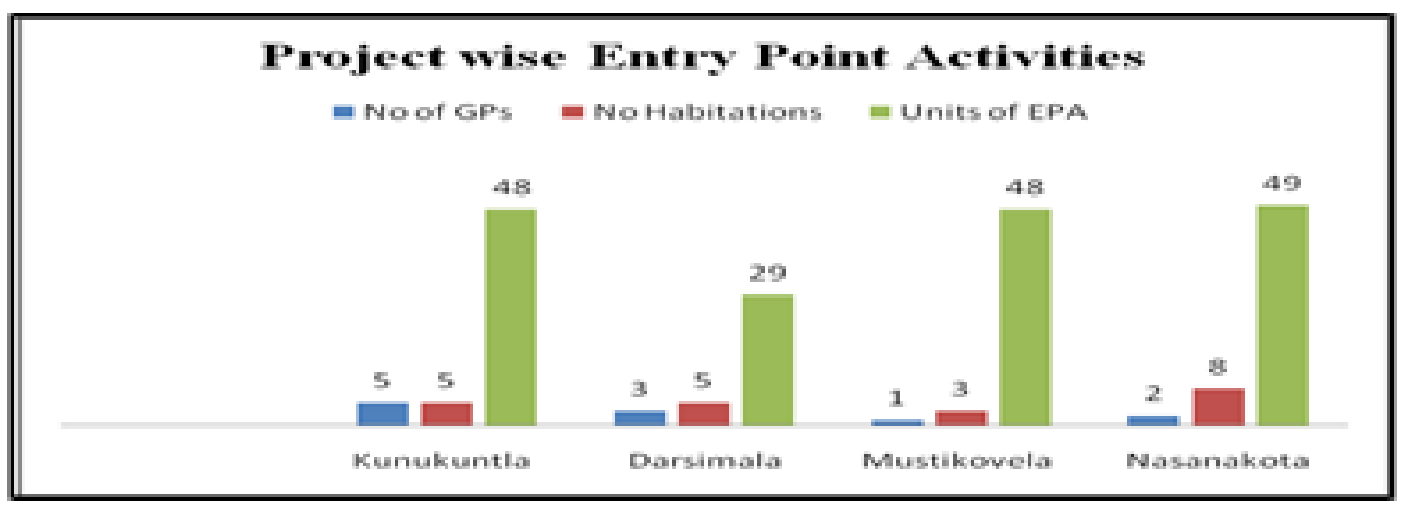

Fig.1
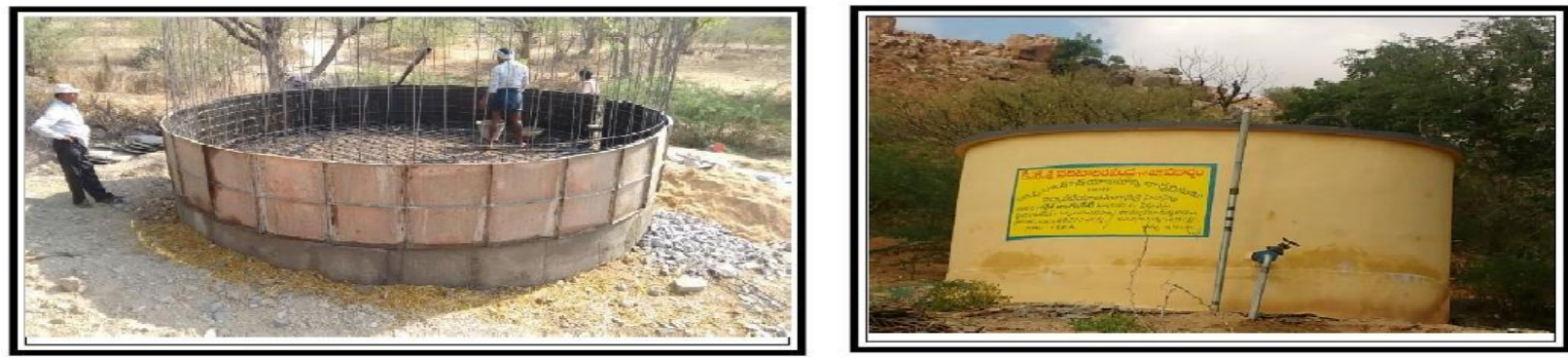

Fig.2 Photos of EPA Activities

Cattle troughs and water plant

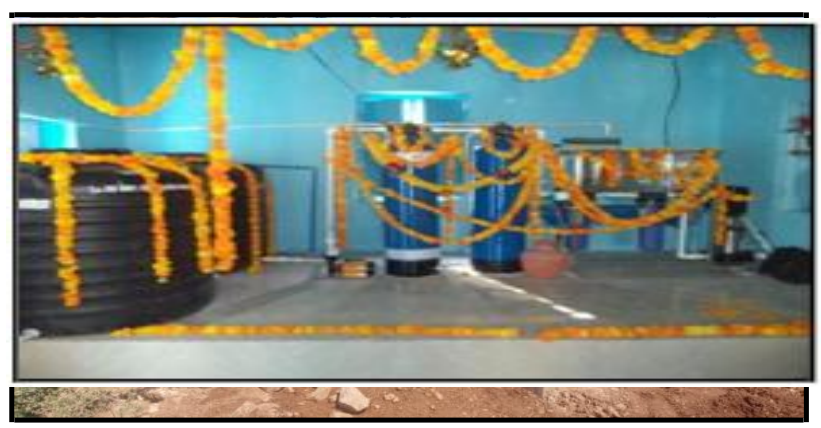

The villagers wisely made use of the project EPA by getting widely acceptable material like, cattle troughs, school furniture, solar streetlights and tent houses. Among these cattle troughs find very useful in villages for drinking water for almost 100 animals daily. In the village, the solar streetlights produced remarkable success, as well as school

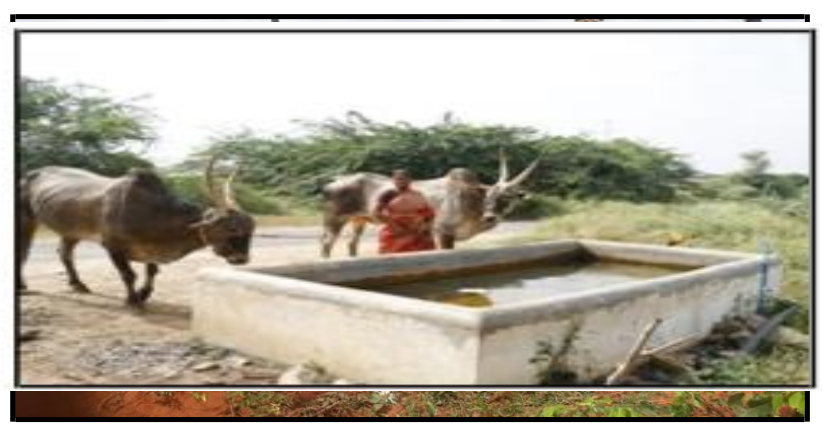

furniture found excellent usefulness. Majority of the EPA programs have become very beneficial to the general community and managed primarily by the community in the watershed villages. The EPA played a vital role in developing the relationship between project implementation agency (PIA) and rural community before setting up watershed 
projects and community-selected EPA initiatives as an example for the sustainable approach in the watershed programme.

\section{IWMP Initiative and their Concern towards Villagers Need}

Guvvalagondhipally micro watershed is located in C. K. Palli mandal of Ananthapur district. The micro watershed was sanctioned in Batch-III under the project of Mustikovela. There are 520 households in this village and 1724 ha of watershed treatable area. Majority of the farmers belong to small and marginal and the primary occupation is agriculture apart from the rearing of animals.

The villagers were facing a drinking water problem for many years. During the implementation of the watershed program, watershed functionaries have conducted grama sabha, kalajata and awareness camps. In these training, they provided the information regarding the importance of the conservation and protection of water and soil and the importance of the groundwater.

All the villagers were participated and extended their support for the planning of watershed in their village for 5 years. They have expressed their difficulties in facing the problem of drinking water due to lack of groundwater in their villages as well as the insufficient supply of government water. In this connection, all the villagers made a collective decision on the construction of the water tank for the village community. Later, watershed committee proposed a plan and asked for permission for the construction of the water tank to overcome the drinking water problem. After that, the villagers constructed a water tank that was accessible to all the people in the village and once the tank is filled with the water these can be used for the next 24 hours. The village communities felt very happy for having available drinking water in their villages and thanked the IWMP initiative and their concern towards people need.

\section{References}

1. Changing rural lives through watershed development-integrated watershed management programme

2. http://watershedpedia.com/role-of-entrypoint-activitiesepa-in-watershedmanagement/

3. Booklet on umlangia watershed iwmp-1 under intergrated watershed management programme batch

4. Operational guidelines of entry point activities

\section{How to cite this article:}

Reddy, P.V. R. M., B. Janardha Reddy, B. V. Ramana Kumar, R. Jhansi Rani and Pullanna Vidyapogu. 2021. Entry Point A Initiatives as an Example for the Sustainable Approach in the Watershed Programme in Anantapur District, Andhra Pradesh. Int.J.Curr.Microbiol.App.Sci. 10(04): 329-340. doi: https://doi.org/10.20546/ijcmas.2021.1004.035 